\title{
Production of Self-fluxing Pellets at Hirohata Works of Nippon Steel Corporation*
}

\author{
By Akira TAYAMA,** Yasuto SHIMOMURA, ** Keiki FUJITA*** \\ and Tetsuro TAKEMURA***
}

\begin{abstract}
Synopsis
Nippon Steel Corporation set up a pellet plant having the capacity of 2.5 million t/year at Hirohata Works (Hirohata Pellet Plant) and in February 1973 started the production of self-fluxing pellets having a basicity of 1.2 .

The construction and operation of this pellet plant, the characteristics of self-fluxing pellets produced, and operational data of pellets as used in blast furnaces are reported in this paper. The Hirohata Pellet Plant, constructed for the production of self-fluxing pellets from slurry of iron ores, is equipped with a slurry pipeline, a storage pond, etc., specially designed for the purpose. The firing furnace of grate kiln type was adopted to produce uniformly baked homogeneous pellets. The product pellets are superior to acid pellets in the properties such as the reducibility, swelling during reduction, and high-temperature characteristics under load, and behave excellently in the blast furnace.
\end{abstract}

\section{Introduction}

The Hirohata Pellet Plant has been in operation for about 3 years, stably producing pellets of good quality. The pellet production of this plant reached 2.5 million $\mathrm{t} /$ year and a maximum daily level of $8600 \mathrm{t}$, contributing to the high blast furnace productivity and reduction of fuel rate.

Descriptions of the construction, equipment and operation of the pellet plant, the characteristics of self-fluxing pellets produced, and the operational data on pellets used in blast furnaces will be given in this report.

\section{Construction of the Hirohata Pellet Plant}

\section{Basic Concept and Requirements}

In order to improve the blast furnace productivity and to reduce the fuel rate, a plan for strengthening ore agglomeration facilities was studied when the sinter ratio of blast furnace burden became $45 \%$ following the blow-in of Hirohata No. 4 Blast Furnace in June 1970. Two alternatives in the plan were: (1) addition of a new sinter plant and (2) construction of a new pellet plant. After comparative studies and discussions, the construction of a new pellet plant was adopted for the following reasons.

(1) The necessity of utilizing finer size iron ores in the future was infallible.

Utilization of ore fines consisting mainly of blue dust would be imperative. In addition, more and more mines would separate from ores such components as $\mathrm{S}, \mathrm{Cu}, \mathrm{P}$, etc., which are detrimental to steelmaking by use of ore preparation processes including crushing, magnetic separation and floatation for grading up lean ores. Therefore, a combination of sintering and pelletizing processes would be advantageous in view of the effective use of iron ores.

(2) High quality self-fluxing pellets would improve blast furnace operation.

When it is used in blast furnace burden, self-fluxing pellets of high reducibility and good characteristics after reduction would reduce the fuel rate and increase the productivity, and hence it would greatly improve the blast furnace operation.

(3) The use of slurried ore fines would significantly facilitate the handling work.

In addition, because dust problems could be eliminated, ore handling in slurry form would be highly advantageous in view of environmental protection.

Based on the concept described above, a construction plan was made so as to have a pelletizing capacity of 2.5 million t/year using slurried Peruvian ores (at first they were called as Marcona ores) at a blending ratio of $35 \%$.

\section{Construction Timetable}

August, 1969

September 18, 1971 Foundation work for the main facility and the construction of the storage pond were undertaken.

January 27, 1972 Erection of building pillars was celebrated.

November 16, 1972 The storage pond was completed; the first vessel carrying slurry called at the Works' port.

January 20, 1973 Overall trial operation of the facility started.

February 22, 1973 The pellet plant went into operation on a commercial scale.

\section{Outline of the Plant Facility}

Figures 1 and 2 and Table 1 show, respectively, the layout, a flow diagram depicting the principal units and auxiliaries, and the specifications for the main equipment of the pellet plant.

\section{Features of the Plant Equipment}

Features of the Hirohata Pellet Plant are as follows.

(1) Raw materials: Three different raw materials are supplied to the pellet plant, i.e., iron-ore

* Originally published in Seitetsu Kenkyu, (1976), No. 288, 26, in Japanese. English version received March 8, 1977.

** Hirohata Works, Nippon Steel Corp., Fuji-cho, Hirohata-ku, Himeji 671-11.

*** Head Office, Nippon Steel Corp., Otemachi, Chiyoda-ku, Tokyo 100. 


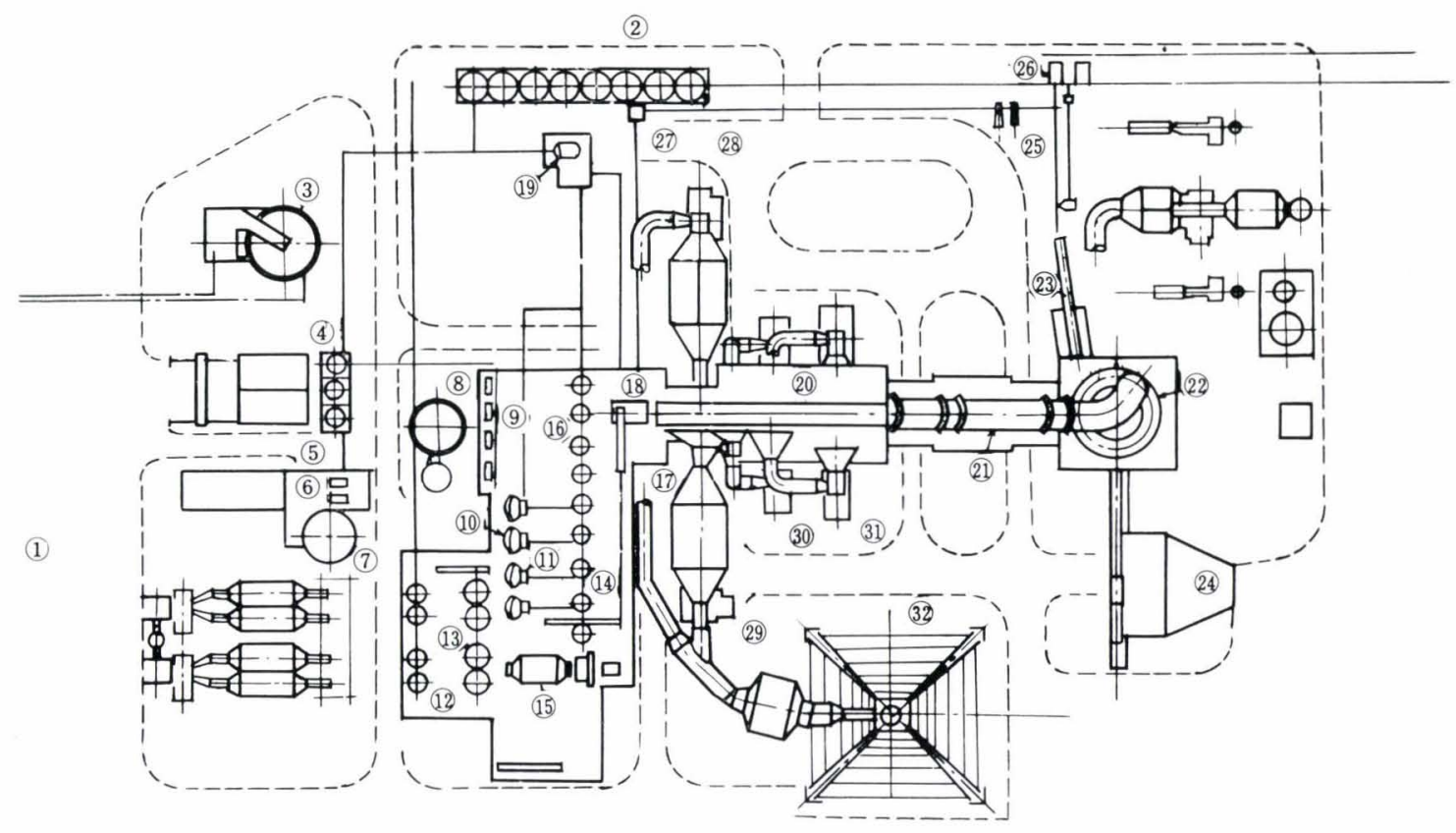

\begin{tabular}{|c|c|c|c|c|c|c|c|c|c|c|c|}
\hline No. & Equipment & $\begin{array}{l}\text { Quan- } \\
\text { tity }\end{array}$ & No. & Equipment & $\begin{array}{l}\text { Quan- } \\
\text { tity }\end{array}$ & No. & Equipment & $\begin{array}{l}\text { Quan- } \\
\text { tity }\end{array}$ & No. & Equipment & $\begin{array}{c}\text { Quan- } \\
\text { tity }\end{array}$ \\
\hline 1 & Storage poud & 1 & 9 & Vaccum filter & 4 & 17 & $\begin{array}{l}\text { Reciprocating } \\
\text { belt }\end{array}$ & 1 & 25 & Classifier & 1 \\
\hline 2 & $\begin{array}{l}\text { Raw material } \\
\text { bin }\end{array}$ & 8 & 10 & Disk pelletizer & 7 & 18 & Feed conveyor & 1 & 26 & Product screen & 1 \\
\hline 3 & Thickener & 1 & 11 & Seed screen & 7 & 19 & Drum mixer & 1 & 27 & Return hopper & 1 \\
\hline 4 & Cake hopper & 1 & 12 & $\begin{array}{l}\text { Mill feed } \\
\text { hopper }\end{array}$ & 4 & 20 & Grate & 1 & 28 & Return hopper & 1 \\
\hline 5 & Bentonite bin & 2 & 13 & Air separator & 4 & 21 & Rotary kiln & 1 & 29 & Drying fan & 2 \\
\hline 6 & Pug mill & 2 & 14 & $\begin{array}{l}\text { Raw material } \\
\text { bin }\end{array}$ & 7 & 22 & Annular cooler & 1 & 30 & $\begin{array}{l}\text { Dehydration } \\
\text { fan }\end{array}$ & 2 \\
\hline 7 & Blending silo & 1 & 15 & Ball mill & 2 & 23 & Straight cooler & 1 & 31 & Preheat fan & 2 \\
\hline 8 & Agitator tank & 1 & 16 & Mixer hopper & 4 & 24 & Lump pit & 1 & 32 & Main stack & 1 \\
\hline
\end{tabular}

Fig. 1. Layout of the Hirohata Pellet Plant

slurry (Peruvian ores), ground ores and direct pellet feed.

(2) Slurry handling: Slurry receiving and conveying pipelines, a storage pond lined with rubber sheets for preventing slurry leakage, a dredger for discharging slurry from the pond, a thichener, an agitator, vacuum filters, etc., are installed for slurry handling.

(3) Ore grinding: A closed-circuit ball mill is used together with hot-air drying of materials. In the ore grinding process, limestone is mixed with ores in order to keep the basicity of pellets constant and make the structure of pellets uniform.

(4) Fret mills are adopted as a mixing unit to obtain good pellet properties.

(5) Disk pelletizers are used.

(6) A grate kiln type machine is adopted for uniform baking of pellets.

(7) The grate is of the 3-chamber type having 3 functions of drying, dehydrating and preheating.

(8) The following environmental measures are adopted.

(i) A bag filter is installed to collect dust generated in handling of ore fines. (ii) An electric precipitator is used to remove dust from combustion exhaust.

(iii) Water is recirculated in order to prevent water contamination by effluent.

(iv) Silencers are installed to suppress noise from blowers and fans.

(v) Afforestation is provided around the pellet plant for environmental improvement.

The system for receiving and sending ore slurry, which is an integral part of the plant facility, will be described below.

\section{Iron Ore Slurry System ${ }^{11}$}

Peruvian ores, consumption of which at this pellet plant amounts to approximately 1 million $t$ annually, are transported in slurry form by two slurry transport vessels. Because the MS "Marcona Merchant", one of the two vessels, was already in service with its slurry pump capacity fixed, a land booster station was installed to cover the unloading capacity of the slurry pumps on board the vessel. The other slurry transport vessel, the MS "Exporter", built concurrently with the construction of the Hirohata Pellet Plant, was designed after consultation with Marcona Corpo- 


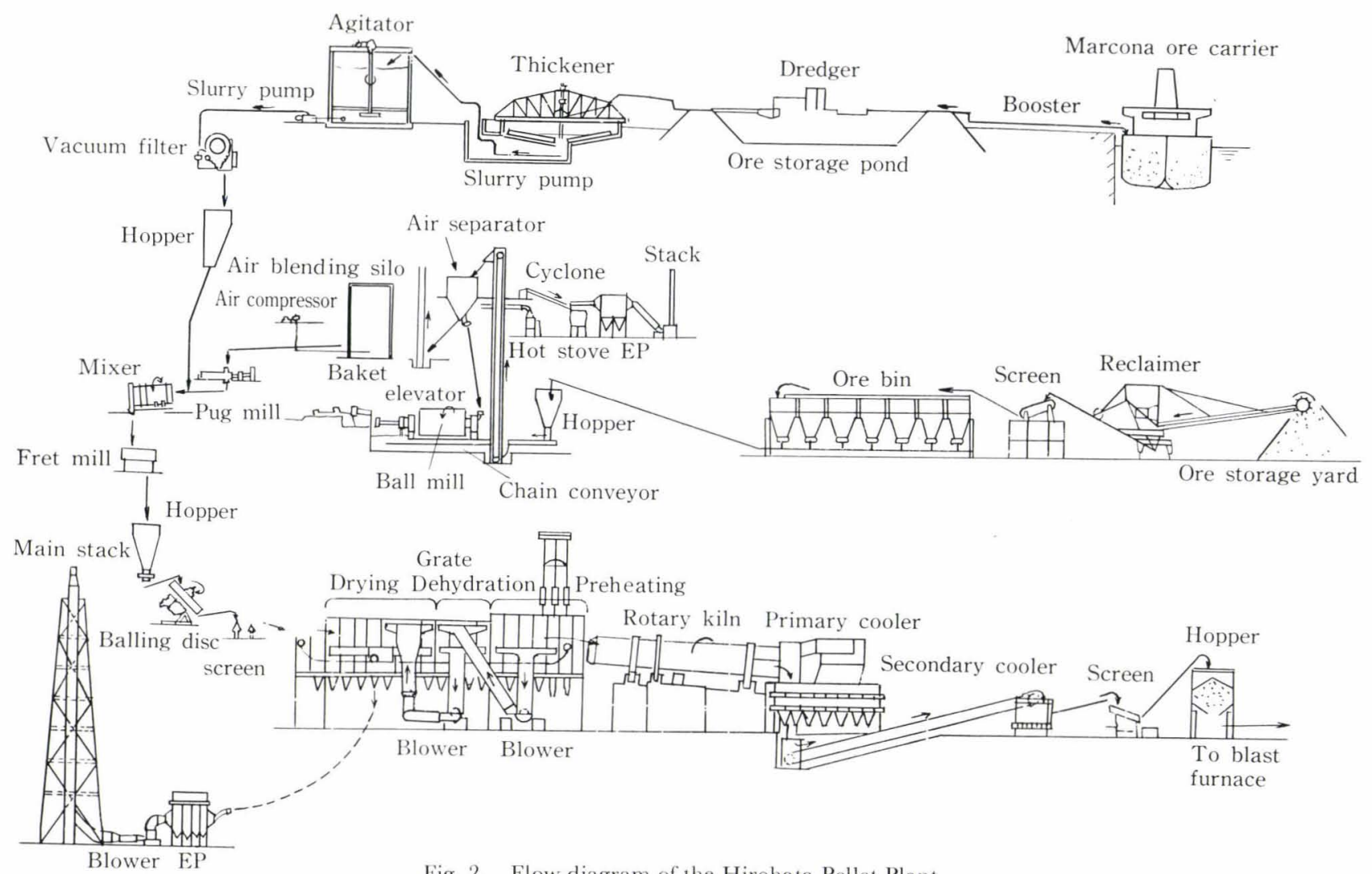

Fig. 2. Flow diagram of the Hirohata Pellet Plant

Table 1. Specifications for the main equipment of the Hirohata Pellet Plant

\begin{tabular}{|c|c|c|}
\hline Equipment & $Q^{\prime}$ ty & Specification \\
\hline $\begin{array}{l}\text { Slurry dehydrating equipment } \\
\text { (1) Thickener } \\
\text { (2) Agitator tank } \\
\text { (3) Vacuum filter }\end{array}$ & $\begin{array}{l}1 \\
1 \\
4\end{array}$ & $\begin{array}{l}17.0 \mathrm{~m} \text { dia. } \times 3.5 \mathrm{~m} \text { depth } \\
12.0 \mathrm{~m} \text { dia. } \times 11.5 \mathrm{~m} \text { depth } \\
\text { Disk type with agitator } \\
2.1 \mathrm{~m} \text { dia. } \times 12 \text { disks }\end{array}$ \\
\hline $\begin{array}{l}\text { Raw materials drying, } \\
\text { crushing, humidifying and } \\
\text { mixing equipment } \\
\text { (4) Air separator } \\
\text { (5) Ball mill } \\
\text { (6) Air blending silo } \\
\text { (7) Pug mill } \\
\text { (8) Drum mixer } \\
\text { (9) Fret mill }\end{array}$ & $\begin{array}{l}4 \\
2 \\
1 \\
2 \\
1 \\
4\end{array}$ & $\begin{array}{l}5.5 \mathrm{~m} \text { dia. } \times 9.0 \mathrm{~m} \text { depth }(450 \mathrm{t} / \mathrm{hr}) \\
5.1 \mathrm{~m} \text { dia. } \times 9.1 \mathrm{~m} \text { length } \\
11.0 \mathrm{~m} \text { dia. } \times 16.5 \mathrm{~m} \text { depth }\left(1000 \mathrm{~m}^{2}\right) \\
0.8 \mathrm{~m} \text { dia. } \times 4.5 \mathrm{~m} \text { length }(220 \mathrm{t} / \mathrm{hr}) \\
2.6 \mathrm{~m} \text { dia. } \times 4.6 \mathrm{~m} \text { length }(460 \mathrm{t} / \mathrm{hr}) \\
\text { Simpson type Model MS }-23 \mathrm{G}\end{array}$ \\
\hline $\begin{array}{l}\text { Pelletizing equipment } \\
\text { (10) Pelletizer } \\
\text { (11) Green pellet screen }\end{array}$ & $\begin{array}{l}7 \\
7\end{array}$ & $\begin{array}{l}6.0 \mathrm{~m} \text { dia. } \times 0.8-1.1 \mathrm{~m} \text { depth } \\
1.8 \mathrm{~m} \text { width } \times 5.5 \mathrm{~m} \text { length }\end{array}$ \\
\hline $\begin{array}{l}\text { Firing equipment } \\
\text { (12) Travelling grate } \\
\text { (13) Rotary kiln } \\
\text { (14) Annular cooler } \\
\text { (15) Straight cooler } \\
\text { (16) Product screen }\end{array}$ & $\begin{array}{l}1 \\
1 \\
1 \\
1 \\
2\end{array}$ & $\begin{array}{l}4.7 \mathrm{~m} \text { width } \times 58.6 \mathrm{~m} \text { length } \\
6.6 \mathrm{~m} \text { dia. } \times 46.0 \mathrm{~m} \text { length } \\
17.0 \mathrm{~m} \text { dia. } \times 2.5 \mathrm{~m} \text { width } \\
1.8 \mathrm{~m} \text { width } \times 22.2 \mathrm{~m} \text { length } \\
2.1 \mathrm{~m} \text { width } \times 6.1 \mathrm{~m} \text { length }\end{array}$ \\
\hline $\begin{array}{l}\text { Other equipment } \\
\text { (17) Slurry storage pond } \\
\text { (18) Stack }\end{array}$ & $\begin{array}{l}1 \\
1\end{array}$ & $\begin{array}{l}9.0 \mathrm{~m} \text { water depth, } 210000 \mathrm{~m}^{2} \text { capacity } \\
210 \mathrm{~m} \text { height } \times 4.5 \mathrm{~m} \text { dia. }\end{array}$ \\
\hline
\end{tabular}

ration to be able to unload slurry of average weight concentration of $70 \%$ at a rate of $4000 \mathrm{t} / \mathrm{hr}$. The slurry pumps and the pipeline meeting the above requirements were designed and installed on board the vessel and on land, respectively. (At present only the MS "Exporter" is in service.)

\section{Slurry Properties}

(1) Chemical Composition and Particle Size

Table 2 shows typical chemical composition and particle size distribution of Peruvian ore slurry.

(2) Fluidity

A test apparatus was set up in Hirohata Works to investigate and study the effects of slurry properties on the slurry line, such as those on the optimum flow rate, design of bends, wear of pipe, pipe clogging by highly concentrated slurry when left for a long time, change in the density of slurry in a storage pond after long storage, the effect of slurry concentration on the pressure loss of straight horizontal pipe, etc. Figure 3 shows the natural settling velocity curves according to different concentrations of slurry.

\section{Slurry Transport Vessels}

A general arrangement of the MS "Exporter" is shown in Fig. 4. Installed in the lower part of each hold are $6 \sim 8$ jet nozzles which jet out fresh water under a pressure of $40 \mathrm{~kg} / \mathrm{cm}^{2}$ to cut slurry in the hold and collect it into the collecting tank, from which slurry is sent under pressure by slurry pumps.

\section{Slurry Piping}

The piping layout is shown in Fig. 5. The pipeline extends $1600 \mathrm{~m}$ from the unloading wharf to the ore storage pond. The key points taken into consideration for the design of the pipeline are as follows.

(1) The radius of bends was decided so as to be $R \geqq 20 D$ in consideration of pressure loss and wear of pipe.

(2) Pipes were laid on supports so that those requiring replacement due to wear could be removed or rotated.

(3) Pipes made of NSC's special steel " MARILOY " were used for the locations in the seawater 
Table 2. Chemical composition and particle size of peruvian ore slurry

Chemical composition (\%)

Typical particle size

\begin{tabular}{ccccccccccccc} 
T. Fe & $\mathrm{SiO}_{2}$ & $\mathrm{Al}_{2} \mathrm{O}_{3}$ & $\mathrm{~S}$ & $\mathrm{P}$ & $\mathrm{Cu}$ & $\mathrm{CaO}$ & $\mathrm{FeO}$ & $\mathrm{Na}_{2} \mathrm{O}$ & $\mathrm{K}_{2} \mathrm{O}$ & $\begin{array}{c}-100 \mathrm{mesh} \\
(\%)\end{array}$ & $\begin{array}{c}-325 \mathrm{mesh} \\
(\%)\end{array}$ & $\begin{array}{c}\mathrm{SW} \\
(\mathrm{cm} / \mathrm{g})\end{array}$ \\
\hline $69 \sim 70$ & $1.1 \sim 2.0$ & $0.2 \sim 0.4$ & $0.17 \sim 0.23$ & 0.01 & 0.005 & 0.03 & 30 & 0.30 & 0.07 & 98 & $68 \sim 70$ & 1450
\end{tabular}

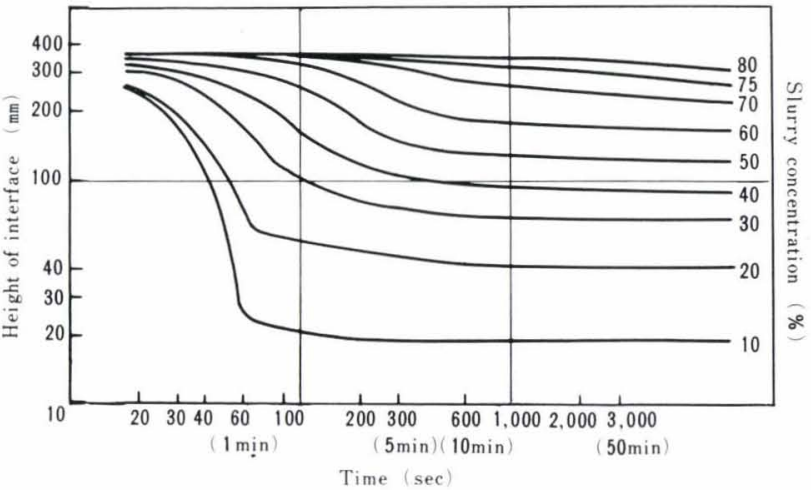

Fig. 3. Natural sedimentation velocity curves according to slurry concentrations
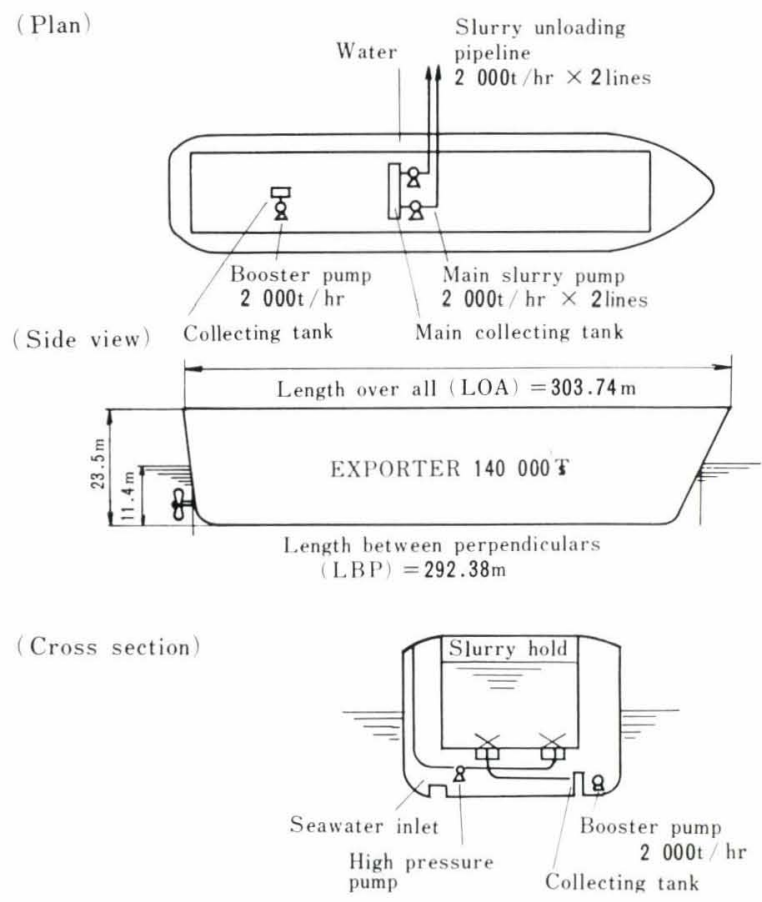

Fig. 4. Structure of MS "SAN JUAN EXPORTER"

splash zone on the wharf and partially in the area where pipes were buried underground.

\section{Slurry Storage Pond}

A cross section of slurry storage pond is shown in Fig. 6. The pond is $190 \mathrm{~m}$ long, $160 \mathrm{~m}$ wide and $9 \mathrm{~m}$ deep, and has a maximum ore storage capacity of $270000 \mathrm{t}(220000 \mathrm{t}$ in the effective capacity) and a maximum slurry deposit depth of $5 \mathrm{~m}$. In order to make the embankment and the bottom of the pond impervious, it was lined with rubber sheets, considering the water resistance of rubber, adaptability to ground subsidence, stability against earthquakes, impermeability to water, economics, maneuverability of

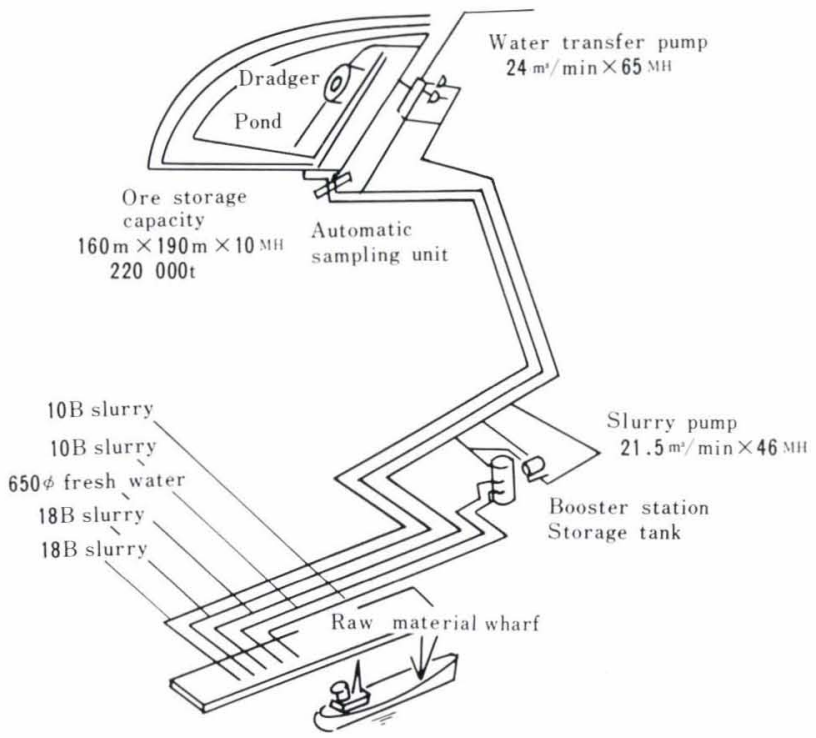

The pipeline extends approximately $1600 \mathrm{~m}$ from the wharf to the pond.

Fig. 5. Layout of slurry unloading equipment at Hirohata Works

dredger, etc. Rubber sheets made of ethylene-propylene terpolymer (EPT), having a thickness of 1.5 $\mathrm{mm}$ were used.

\section{Operation}

\section{Operating Method}

Refer to the flow diagram shown in Fig. 2.

At the Hirohata Pellet Plant, three types of ore are used, namely, Peruvian ore in slurry form, hematite ore which is ground before use, and direct pellet feed stored in the ore yard.

Slurry is sent from the pond to the thickener, then to the agitator, and to the vacuum filter for water removal, and is stored in the cake hopper.

Ores are ground together with limestone by the dry type closed-circuit ball mill to a specific surface area of approximately $4000 \mathrm{~cm}^{2} / \mathrm{g}$ and are stored in the air-blending silo. The ground ores discharged from the silo, dehydrated cake of Peruvian ores, direct pellet feed and bentonite are all mixed in the drum mixer, further mixed well by the fret mill, and sent to the disk pelletizer. The green pellets are charged into the grate furnace, going through the drying process for the removal of surface water, the dehydrating process for the removal of combined water, and the preheating process for heating and strengthening the pellets. Then, the pellets are charged into the rotary kiln, where they are baked while being roted. Thate retention time and the firing temperature in the kiln differ according to the properties of raw materials and 


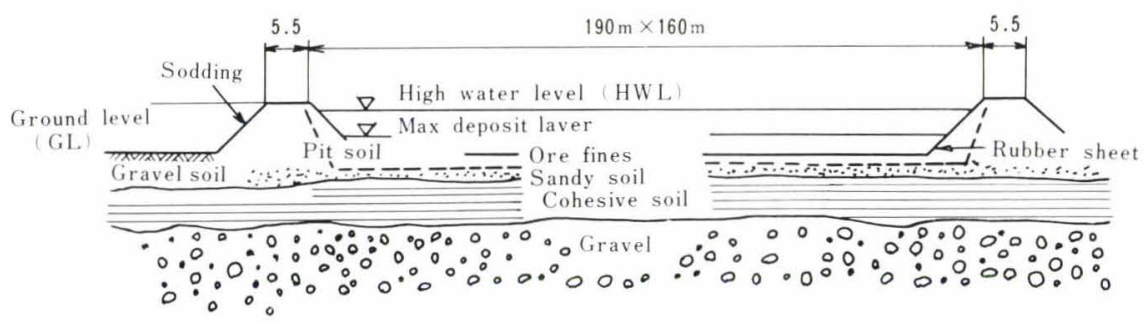

Gross capacity : $210,000 \mathrm{~m}^{3}$

Ore fines: $220000 \mathrm{t}$ (effective capacity

Fig. 6. Cross section of slurry storage pond
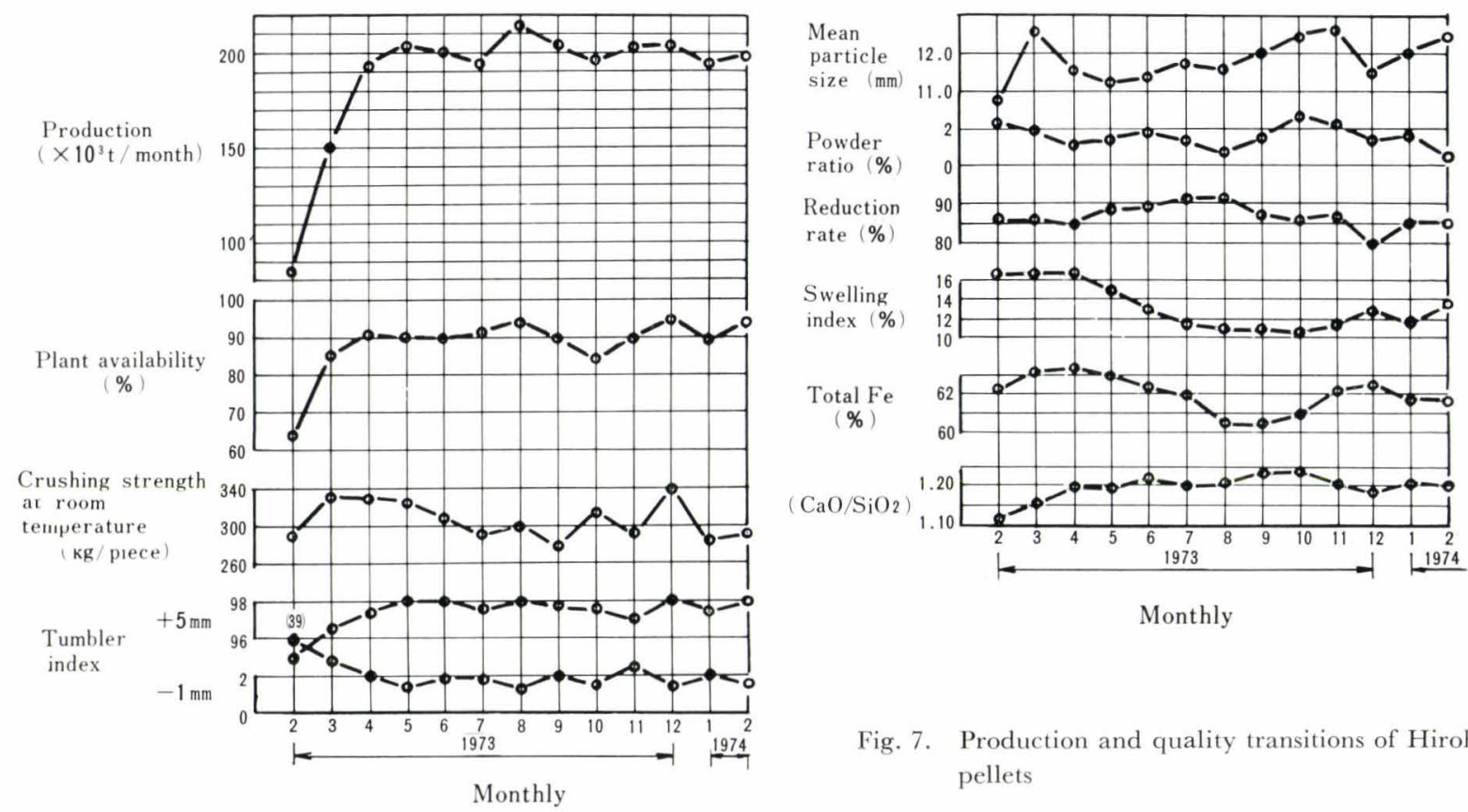

Fig. 7. Production and quality transitions of Hirohata pellets

the quality requirements of product pellets. The fired pellets are gradually cooled by the annular cooler and the straight cooler, screened down to $-5 \mathrm{~mm}$ size, and sent to the blast furnace.

\section{Operation during Start-up $p^{2)}$}

Figure 7 shows the production and the quality of pellets during the year after the start of operation in February, 1973. Start up after hot run was smooth and a monthly production of $200000 \mathrm{t}$ was attained in May of the same year. In March, 1974, the original plan for a cumulative annual production of 2.5 million $\mathrm{t}$ was almost achieved.

The availability of the plant was as high as 90 to $95 \%$ throughout the year except October, (during which troubles occurred in the slurry pumps and the electric system). Operating techniques and equipment were improved to cope with the initial troubles of equipment and change in the brands of raw materials during the first year.

As for the quality of pellets, the swelling index rose to a slightly excessive point immediately after start up, this, however, was improved by efforts to stabilize equipment operation, by raw material adjustment, and by change in the firing method. As a result, all quality targets were attained soon after these measures were taken.

\section{Recent Operation}

Figure 8 shows the data on operation and product

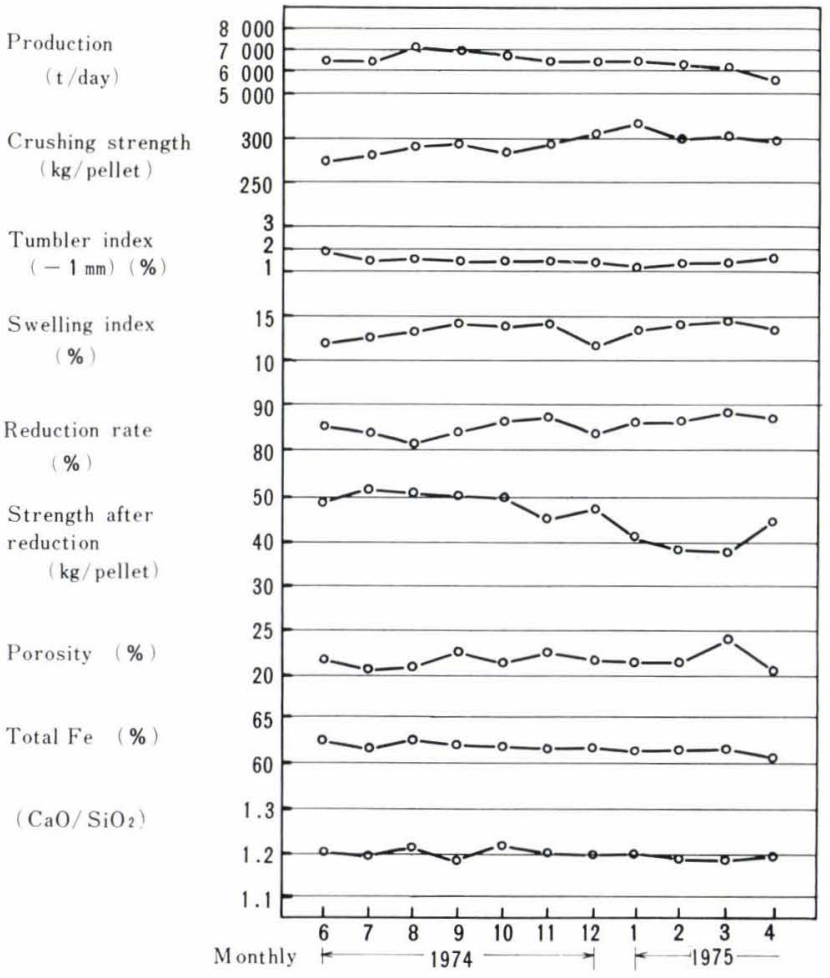

Fig. 8. Recent production and quality transitions of Hirohata pellets

pellet quality attained in the period of June 1974 to April 1975. During this period various operational measures were taken to achieve production targets 
including the production of good quality pellets in quantities as planned and to minimize the energy consumption. The following are the major points of operation.

\section{Securing Good Properties of Green Pellets}

Maintaining good properties of green pellets is a prerequisite for smooth operation in the subsequent process of firing. Green pellets are subjected to impact by dropping them approximately twice from a height of $1 \mathrm{~m}$ and seven times from a height of $50 \mathrm{~cm}$ before they are charged into the grate at the Hirohata Pellet Plant. An essential point of pelletizing operation is therefore to produce green pellets which withstand impacts occurring during conveyance and hence are not subject to size degradation. At Hirohata, a shatter strength of 20 or more is aimed at for green pellets.

Figure 9 shows the effect of the specific surface area of raw materials for blending and that of the swelling factor of bentonite on the shatter strength of green pellets.

\section{Heating Pattern of Grate}

The heating pattern of grate is important, as it may cause surface water and combined water to burst pellets or to induce cracking and thus weaken them prior to charging into the kiln.

Significant improvement was achieved in the product yield as various phenomena appearing on the grate were clarified at the Hirohata Pellet Plant.

\section{Prevention of Fusing in Kiln and Coolers}

Ring formation on the inside surface of kiln or on the grizzly (installed at the discharge end to remove fired pellet rings), or fusion between pellets in the

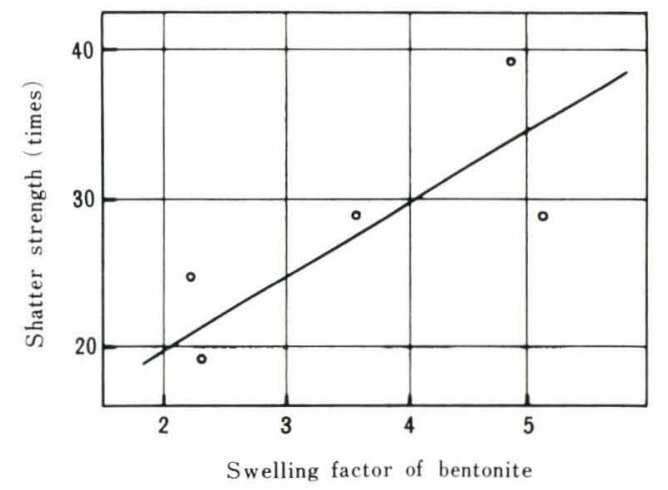

Fig. 9(a). Shatter strength and specific surface area of blending materials

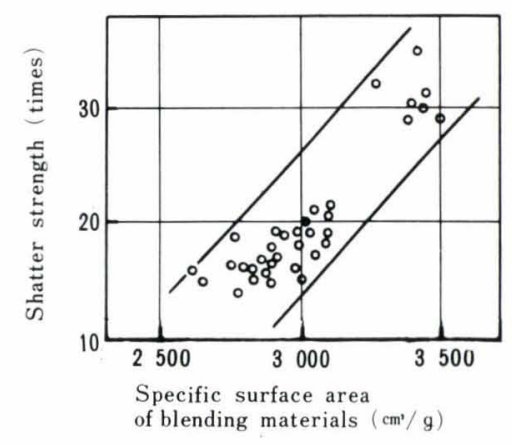

Fig. 9(b). Shatter strength of green pellet annular cooler - either of them brings about difficulty in the stabilizing operation. Because fusion depends on the composition of pellets (especially $\mathrm{FeO}$ and $\mathrm{SiO}_{2}$ contents) and the heat patterns of the kiln and the coolers, control values are set for both raw materials and the heat patterns in an effort to prevent such fusion.

Figure 10 shows the relation between the FeO content of blending materials and fusion in the coolers.

\section{Properties of Self-fluxing Pellets at the Hiro- hata Pellet Plant ${ }^{3}$}

\section{Chemical Composition and Size Distribution}

Tables 3 and 4 show typical chemical composition and size distribution, respectively, of Hirohata pellets.

Items for control are mainly the basicity, slag quantity and mean pellet size.

\section{Microscopic Structure}

Photograph 1 shows typical microscopic structures of Hirohata pellet and imported acid pellet.

Table 5 gives the structural features of Hirohata self-fluxing pellets in comparison with those of acid pellets. Hirohata pellets show a structure where fine particles of iron oxide form together with a small amount of calcium ferrite a continuous network em-

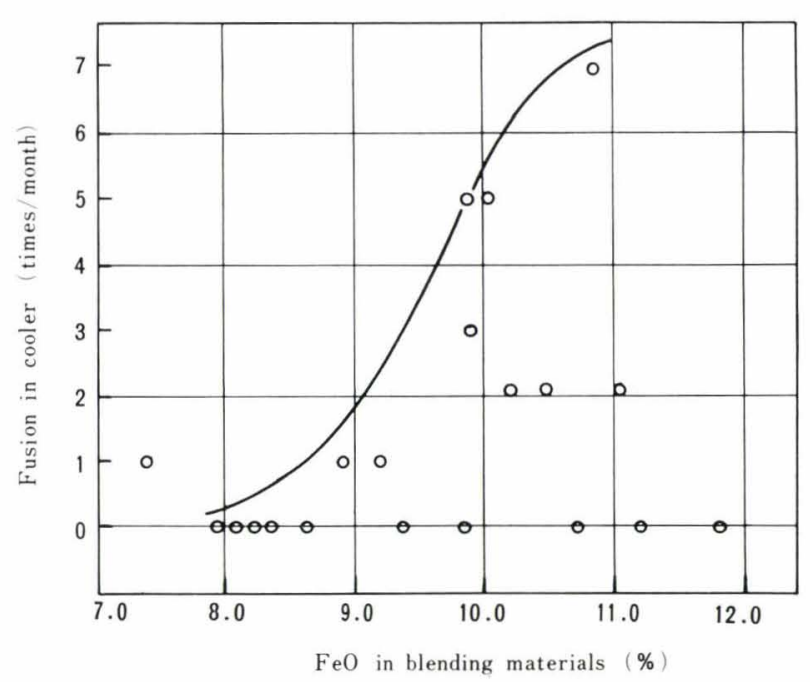

Fig. 10. Relation between $\mathrm{FeO}$ in blending materials and pellet fusion trouble in cooler (Investigated from Feb., 1973 to Feb., 1975)

Table 3. Chemical composition of Hirohata pellets (\%)

\begin{tabular}{ccccccc} 
T. Fe & $\mathrm{SiO}_{2}$ & $\mathrm{Al}_{2} \mathrm{O}_{3}$ & $\mathrm{CaO}$ & $\mathrm{MgO}$ & $\mathrm{S}$ & $\begin{array}{c}\mathrm{CaO} / \\
\mathrm{SiO}_{2}\end{array}$ \\
\hline 62.15 & 3.55 & 1.65 & 4.27 & 0.46 & 0.033 & 1.20
\end{tabular}

Table 4. Size distribution of Hirohata pellets (\%)

\begin{tabular}{cccccc}
$+15 \mathrm{~mm}$ & $15 \sim 10 \mathrm{~mm}$ & $10 \sim 5 \mathrm{~mm}$ & $-5 \mathrm{~mm}$ & $\begin{array}{c}\text { Mean size } \\
(\mathrm{mm})\end{array}$ \\
\hline 14.9 & 65.2 & 18.1 & 1.7 & 12.5 \\
\hline
\end{tabular}




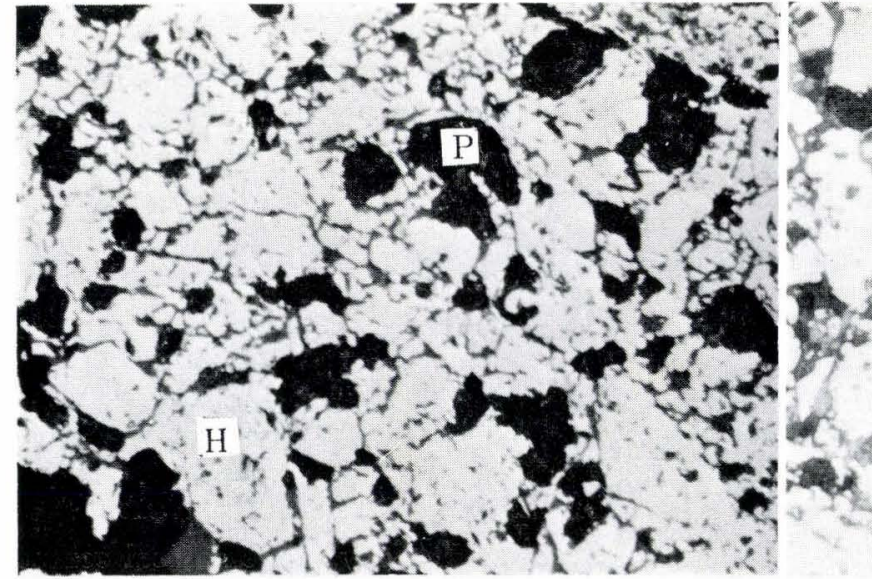

Imported acid pellet

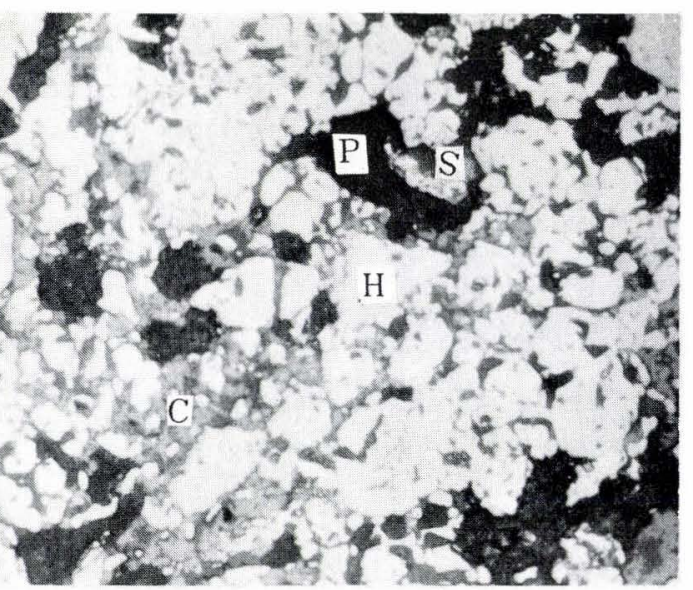

Hirohata self-fluxing pellet

$$
\mathrm{H} \text { : hematite } \mathbf{P} \text { : pore } \mathrm{C} \text { : calcium ferrite } \mathrm{S} \text { : slag }
$$

Photo. 1. Microscopic structure of product pellet

Table 5. Structural features of Hirohata pellets

\begin{tabular}{|c|c|c|c|}
\hline \multicolumn{2}{|c|}{ Item } & Hirohata pellet & Imported acid pellet \\
\hline \multicolumn{2}{|c|}{$\begin{array}{l}\text { Shape or iron } \\
\text { oxide particle }\end{array}$} & $\begin{array}{l}\text { Many are fine particles and } \\
\text { few particles are round in } \\
\text { shape. }\end{array}$ & $\begin{array}{l}\text { Many particles have } \\
\text { grown coarse. }\end{array}$ \\
\hline \multicolumn{2}{|c|}{$\begin{array}{l}\text { Distribution of } \\
\text { iron oxide par- } \\
\text { ticles }\end{array}$} & $\begin{array}{l}\text { Particles remain fine with- } \\
\text { out showing much progress } \\
\text { in recrystallization. }\end{array}$ & $\begin{array}{l}\text { Particles are recrystal- } \\
\text { lized and hematite is } \\
\text { well bound. }\end{array}$ \\
\hline \multicolumn{2}{|c|}{$\begin{array}{l}\text { Pore shape and } \\
\text { distribution }\end{array}$} & $\begin{array}{l}\text { Fine pores are quite uni- } \\
\text { formly distributed. }\end{array}$ & $\begin{array}{l}\text { Pores exist between } \\
\text { recrystallized iron oxide } \\
\text { particles. }\end{array}$ \\
\hline \multicolumn{2}{|c|}{$\begin{array}{l}\text { Slag shape and } \\
\text { distribution }\end{array}$} & $\begin{array}{l}\text { Slag is distributed as a } \\
\text { network, strengthening } \\
\text { structural cohesion. }\end{array}$ & $\begin{array}{l}\text { Because of high total } \mathrm{Fe} \\
\text { slag is not well crystal- } \\
\text { lized. }\end{array}$ \\
\hline \multicolumn{2}{|c|}{$\begin{array}{l}\text { Calcium ferrite } \\
\text { distribution }\end{array}$} & $\begin{array}{l}\text { A small amount of calcium } \\
\text { ferrite exists, connecting } \\
\text { pores. }\end{array}$ & $\begin{array}{l}\text { Calcium ferrite is not } \\
\text { crystallized because of } \\
\text { acidity. }\end{array}$ \\
\hline \multirow{3}{*}{$\begin{array}{l}\stackrel{0}{0} \\
\frac{1}{0} \\
\frac{0}{0} \\
0\end{array}$} & $\begin{array}{l}\text { Total } \\
\text { porosity }\end{array}$ & 24.6 & 22.5 \\
\hline & $\begin{array}{l}\text { Ratio of } \\
\text { open pores }\end{array}$ & 24.4 & 17.8 \\
\hline & $\begin{array}{l}\text { Ratio of } \\
\text { closed pores }\end{array}$ & 0.2 & 4.7 \\
\hline
\end{tabular}

bracing pores of 10 to $20 \mu \mathrm{m}$ in diameter, which are mainly open, distribute uniformly and contribute to smooth diffusion of gas during the period of reduction.

\section{Strength at Room Temperature and Strength after Re- duction}

Relations between the crushing strength at room temperature and the porosity of pellets and also the strength after reduction are shown in Fig. 11. The factors taken up as affecting porosity were heavy oil rate, particle size of raw materials, and $\mathrm{CaO} / \mathrm{SiO}_{2}$, and the operational data on these factors were put to multiple regression analysis. Based on the analytical results, the following regression formula was drawn.

$$
\begin{aligned}
y= & -1.275 \text { (heavy oil rate })-12.16\left(\mathrm{CaO} / \mathrm{SiO}_{2}\right) \\
& -0.278(-325 \#)+92.58
\end{aligned}
$$
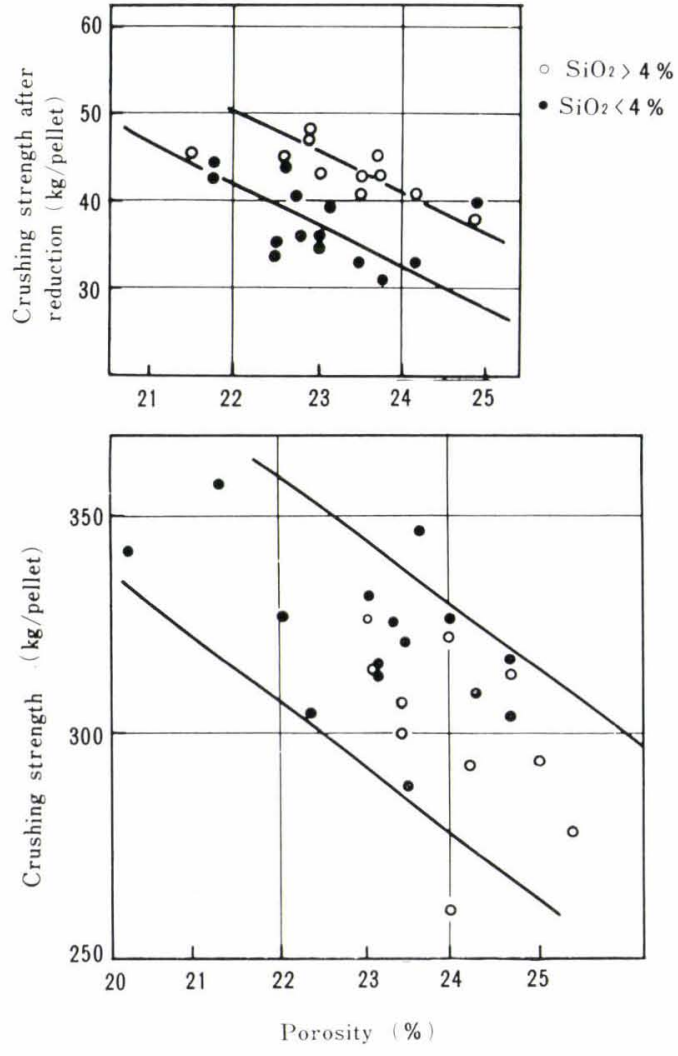

Fig. 11. Relations between porosity and strength

where, $\quad y$ : porosity $(\%)$

Heavy oil rate: Ratio of heavy oil consumption to the weight of dried pellets $(\mathrm{kg} / \mathrm{t})$

-325\#: Percent of undersize through 325 mesh screen

Figure 12 presents the relation between the porosity estimated by the above regression formula and the porosity actually ascertained.

\section{Reduction Swelling}

As is clear from Fig. 13, at about $4 \%$ in $\mathrm{SiO}_{2}$ content swelling of self-fluxing pellets attains a maximum 


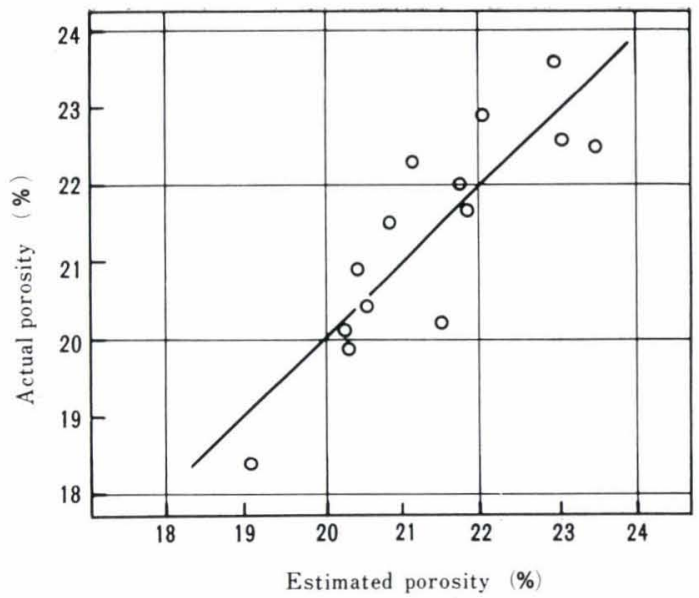

Fig. 12. Relation between estimated porosity and actual porosity

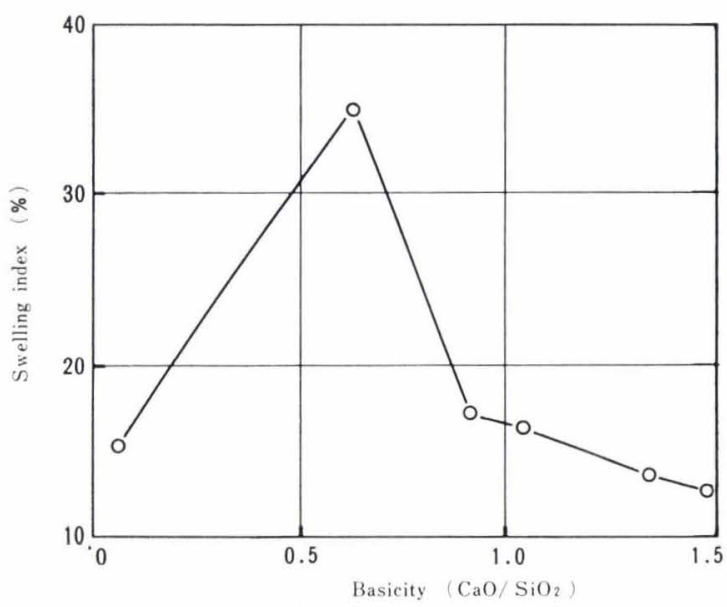

Specimen : baked pellet fired at $1,280^{\circ} \mathrm{C}$

Fig. 13. Relation between basicity and swelling index

when their basicity is approximately 0.5 to $0.7 .4,5$ ) Therefore, it is advisable to avoid this range of basicity. The relation between the $\mathrm{SiO}_{2}$ content and the basicity of self-fluxing pellets is shown in Fig. 14. As is shown from the figure, the swelling property is improved by increasing either $\mathrm{SiO}_{2}$ content or basicity.

The reason why it shows a maximum swelling at the basicity of approximately 0.5 to 0.7 and the stabilization of swelling at lower levels on the higher basicity side can be explained as that the solid solution of slag components in iron oxide and the degree of strain formation (correction gauge content)* govern the swelling of pellets.

The relation between the correction gauge content and the swelling index is shown in Fig. 15. According to this figure, abnormal swelling appears in an area where the ratio of correction gauge content is approximately $9 \%$. For Hirohata pellets, this area is located near $\left(\mathrm{CaO} / \mathrm{SiO}_{2}\right)=0.7$.

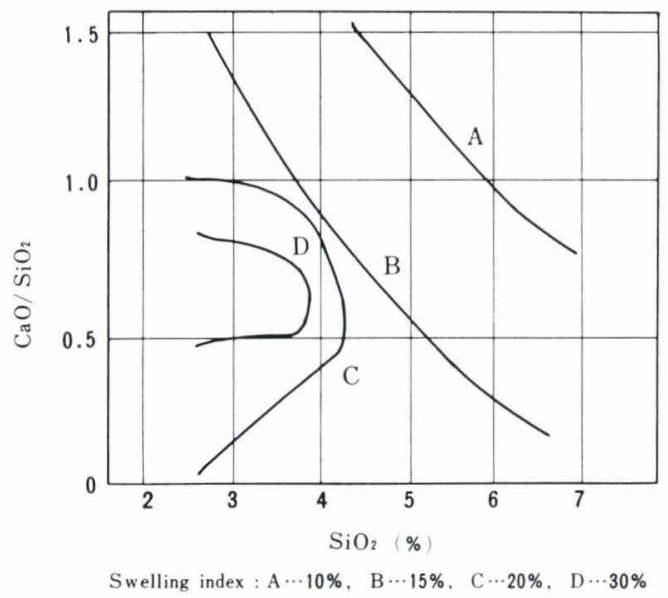

Fig. 14. Iso-swelling lines

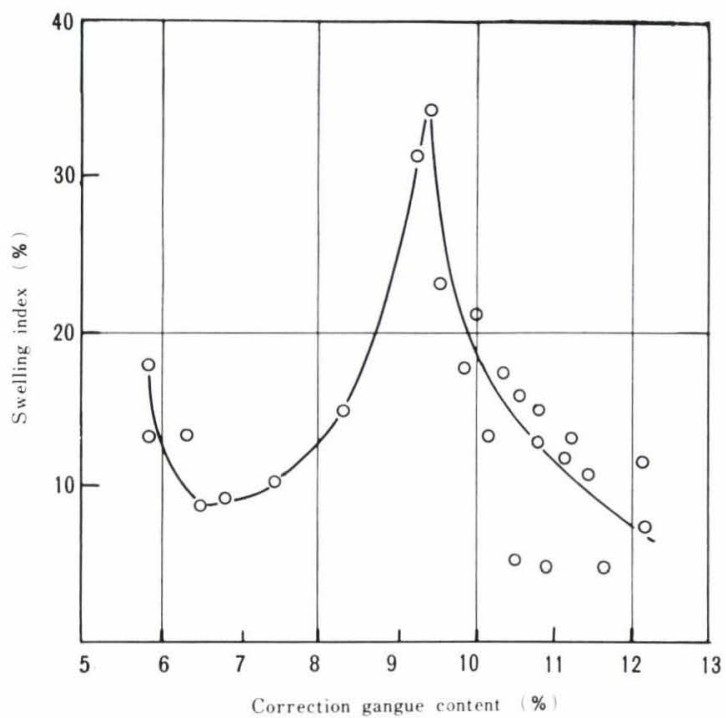

Fig. 15. Relation between correction gangue content and swelling

Figure 16 shows various factors causing swelling of pellets as ascertained in the actual operation of the Hirohata Pellet Plant. They indicate good coincidence with the relation shown in Fig. 14.

\section{Softening Test}

The high temperature characteristics under-load of Hirohata self-fluxing pellets were studied by using the softening test apparatus (a reaction tube of $65 \mathrm{~mm} \phi$, $2.0 \mathrm{~kg} / \mathrm{cm}^{2}$ load, and a temperature range of 0 to $1200^{\circ} \mathrm{C}$ ).

Figure 17 shows the high temperature characteristics under load of Hirohata self-fluxing pellets and those of imported acid pellets. Hirohata pellets have smaller pressure loss and shrinkage at high temperatures than the acid pellets.

* Correction gauge content $=\Sigma\left(\gamma \mathrm{Fe}^{+++} / \gamma\right.$ Slag comp. $) \chi$ Slag comp.

where, $\gamma \mathrm{Fe}^{+++}$: Radius of $\mathrm{Fe}^{+++}$ion

$\gamma$ Slag comp.: Radius of slag component ion

$\chi$ Slag comp.: Percent of slag components (\%)

Slag components: $\mathrm{CaO}, \mathrm{SiO}_{2}, \mathrm{Al}_{2} \mathrm{O}_{3}$ and $\mathrm{MgO}$ 


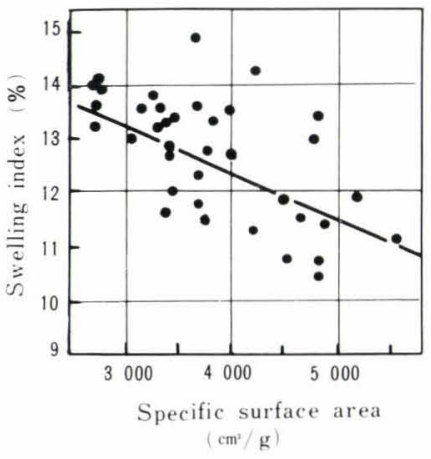

(a) Relation with specific surface area

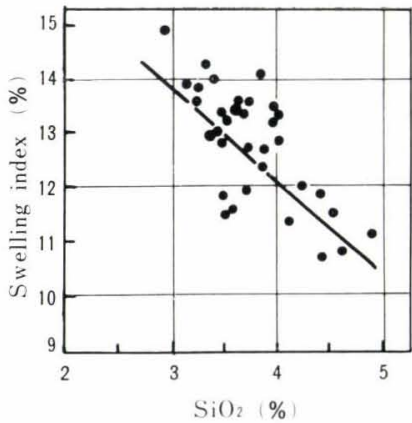

$y=-1.73 x+19.01, \quad \gamma=-0.7135$

(b) Relation with silica

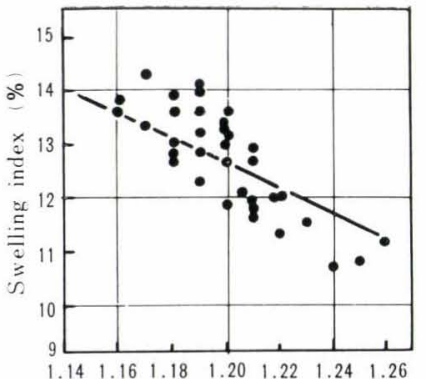

$\mathrm{CaO} / \mathrm{SiO}_{2}$

$y=-24.4 x+41.92, \quad \gamma=-0.4566$

(c) Relation with basicity

Fig. 16. Effects of factors on reduction swelling (actual data)

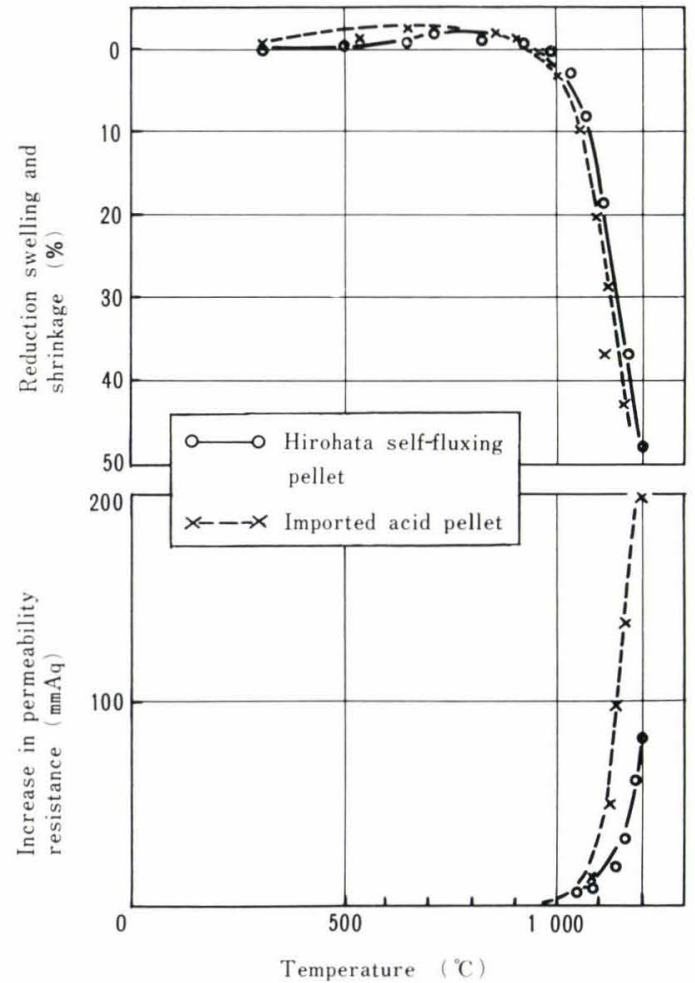

Fig. 17. Under-load high-temperature characteristics of Hirohata self-fluxing pellet

\section{Reduction Rate}

The reduction rate, expressed by the Mckewan's, of Hirohata pellets is compared with that of acid pellets in Fig. 18, where it is shown that, at $1150^{\circ} \mathrm{C}$ the acid pellets are greatly affected by gas diffusion, whereas Hirohata pellets have a large reduction rate due to the rate determining chemical reaction. The reason for this can be explained as that the shape of iron particles and micropores are maintained at high temperatures.

Figure 19 shows the relation between the reduction rate and the specific surface area of blended materials, and the relation between the reduction rate and the porosity. As is clear from the figure, the reduction rate changes with the size distribution of blended materials and the porosity, and a rate as high as 85 to $90 \%$ is attainable.

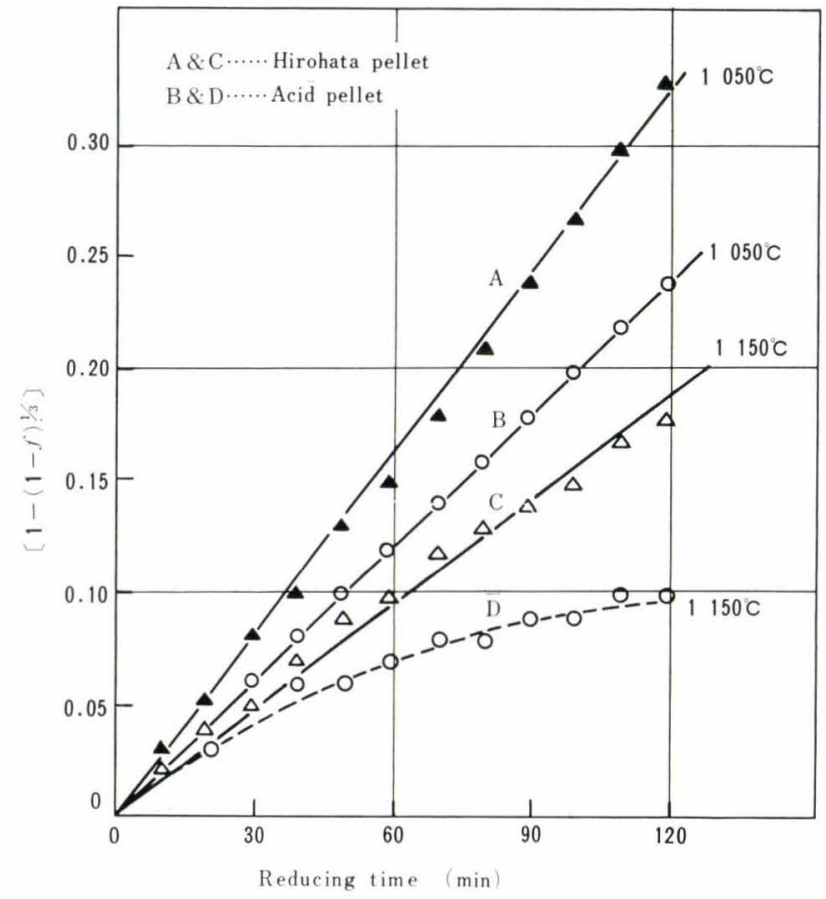

Fig. 18. Results of high temperature reduction test

\section{Control of Apparent Density of Pellets}

As agglomerates of iron oxide, pellets have characteristics correlative to their porosities and densities. Moreover as for the other control items in the pellet plant, it takes much time to get their test results. An apparatus developed by Nippon Steel Corp., for quickly measuring the apparent density of pellets is schematically shown in Fig. 20.6)

Figure 21 shows the distribution of apparent density of Hirohata self-fluxing pellets measured by this apparatus and the relations between the apparent density and the other characteristics. From this graph, correlations between the apparent density and the other characteristics of pellets are clear. Based on these studies, the pellet plant operation is controlled so as to produce pellets whose characteristics fall within the range indicated by the hatched range mark in the graph. 

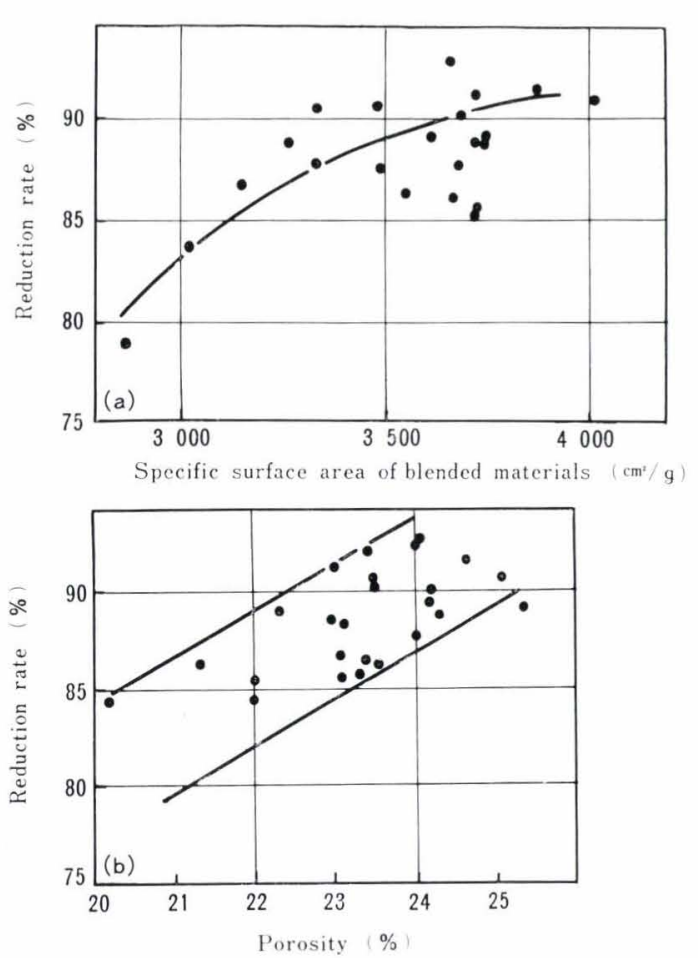

(a) Relation between specific surface area of blended materials and reduction rate

(b) Relation between porosity and reduction rate

Fig. 19. Effects of porosity and particle size of raw materials on reduction rate

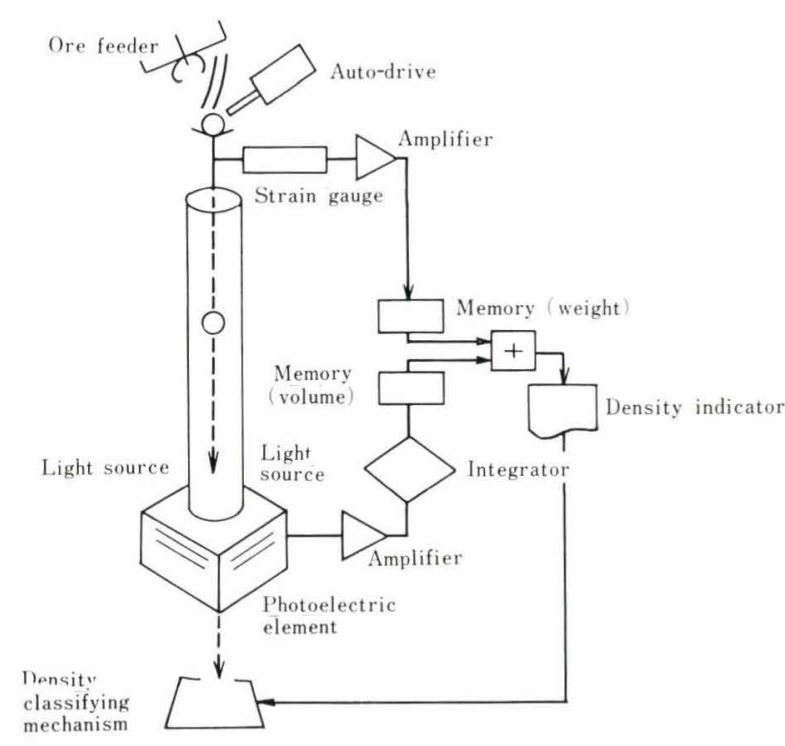

Fig. 20. Apparatus for quickly measuring apparent density

\section{Use of Pellets in Commercial Blast Furnace Operation}

Hirohata self-fluxing pellets were first used in commercial operation in February, 1973.

Operational data of Hirohata No. 4 Blast Furnace for a period covering both before and after the start of using the pellets are given in Table 6 , showing a significant decrease in the fuel rate by the use of the pellets. Afterwards, however, the fuel rate rose slightly due to progressive falling off of throat armor plate of the blast furnace.

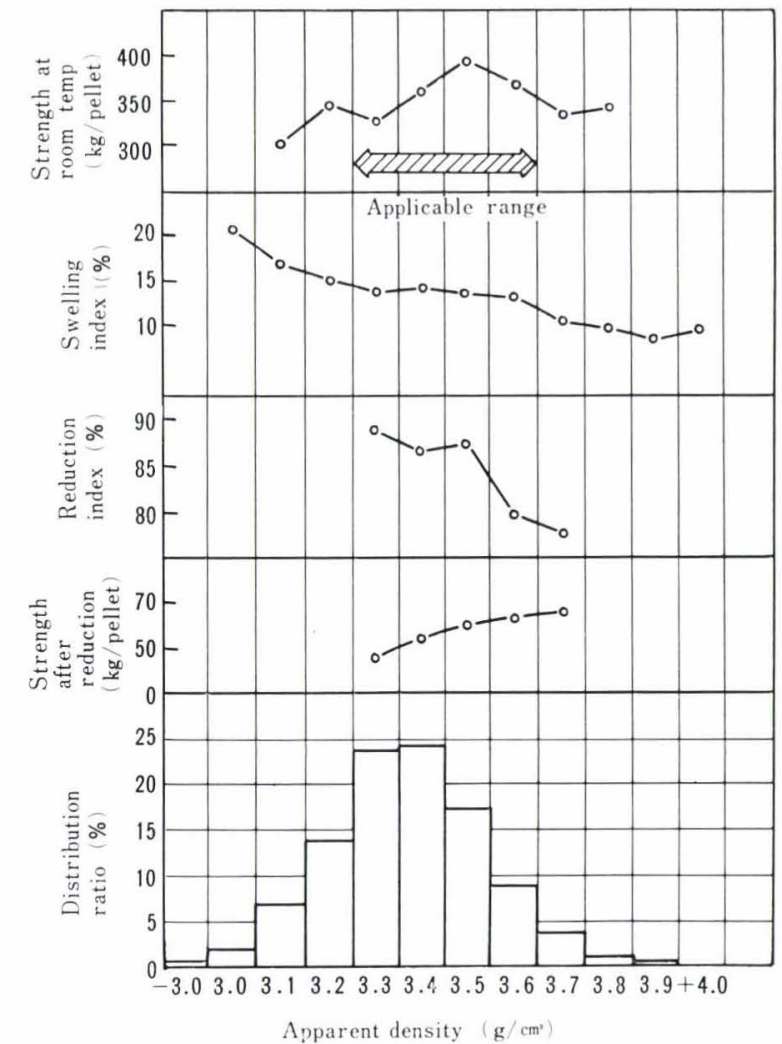

Fig. 21. Apparent density distribution and characteristics of Hirohata pellet

Table 6. Effects of Hirohata self-fluxing pellets (No. 4 B.F.)

\begin{tabular}{|c|c|c|c|c|c|c|}
\hline & \multirow{2}{*}{$\begin{array}{l}1972 \\
\text { Feb. }\end{array}$} & \multicolumn{5}{|c|}{1973} \\
\hline & & Jan. & Feb. & Mar. & Apr. & May. \\
\hline $\begin{array}{l}\text { Self-fluxing } \\
\text { pellet }(\%)\end{array}$ & 0 & 0 & 11 & 30 & 37 & 50 \\
\hline $\begin{array}{c}\text { Acid pellet } \\
(\%)\end{array}$ & 38 & 36 & 21 & 19 & 18 & 5 \\
\hline Sinter $(\%)$ & 36 & 39 & 45 & 39 & 35 & 37 \\
\hline $\begin{array}{c}\text { Production } \\
(\mathrm{t} / \text { day })\end{array}$ & 4939 & 5266 & 5270 & 5723 & 5579 & 5776 \\
\hline $\begin{array}{c}\text { Coke rate } \\
(\mathrm{kg} / \mathrm{t}-\text { pig iron })\end{array}$ & 412.3 & 411.9 & 407.0 & 409.0 & 383.9 & 382.3 \\
\hline $\begin{array}{r}\text { Heavy oil rate } \\
(\mathrm{kg} / \mathrm{t} \text {-pig iron) }\end{array}$ & 74.4 & 73.5 & 73.0 & 53.0 & 74.5 & 75.0 \\
\hline $\begin{array}{c}\text { Fuel rate } \\
(\mathrm{kg} / \mathrm{t} \text {-pig iron })\end{array}$ & 486.6 & 485.3 & 480.0 & 462.0 & 458.4 & 457.3 \\
\hline $\begin{array}{c}\text { Slag rate } \\
(\mathbf{k g} / \text { t-pig iron) }\end{array}$ & 263.1 & 282.2 & 286.8 & 250.0 & 230.4 & 261.0 \\
\hline $\mathrm{Si} \quad(\%)$ & 0.519 & 0.610 & 0.546 & 0.404 & 0.391 & 0.384 \\
\hline $\begin{array}{c}\text { Hanging } \\
\text { (times/month) }\end{array}$ & 13 & 5 & 9 & 0 & 0 & 0 \\
\hline $\begin{array}{c}\text { Slipping } \\
\text { (times/month) }\end{array}$ & 8 & 6 & 10 & 0 & 0 & 0 \\
\hline
\end{tabular}

Figure 22 shows the relation between the pellet blending ratio and the permeability in the blast furnace. Use of acid pellets to a blending ratio of $30 \%$ and beyond induces a permeability problem, whereas Hirohata self-fluxing pellets permit the blending ratio up to $60 \%$ without any appreciable increase in the pressure loss.

It is important to note, however, that, because of a comparatively small angle of repose of pellets, as the 


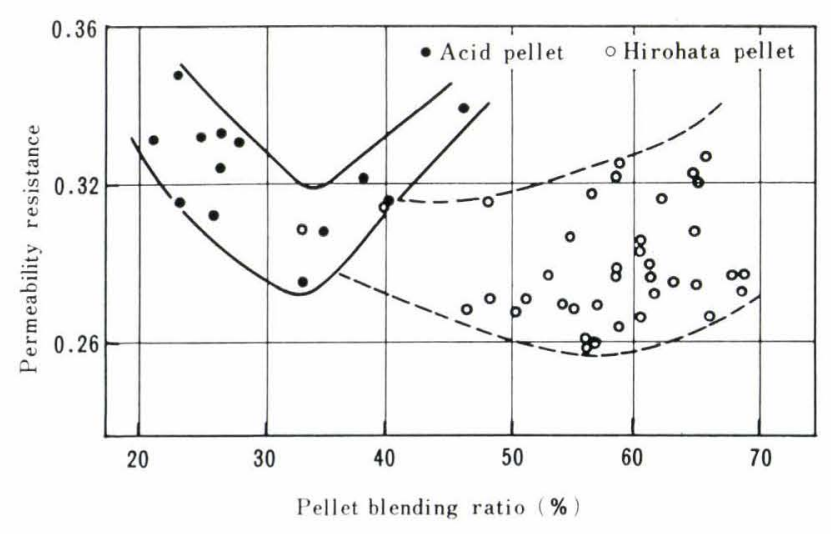

Note: Permeability resistance $=(B P-T P) /(1.2-$ $\mathrm{BV}-2 \mathrm{O}_{2}$ )

where, BP: Blast pressure $\left(\mathrm{kg} / \mathrm{cm}^{2}\right)$

TP: Top pressure $\left(\mathrm{kg} / \mathrm{cm}^{2}\right)$

BV: Blast volume $\left(\mathrm{Nm}^{3} / \mathrm{min}\right)$

$\mathrm{O}_{2}$ : Oxygen flow $\left(\mathrm{Nm}^{3} / \mathrm{min}\right)$

Fig. 22. Relation between pellet blending ratio and permeability resistance in the blast furnace

blending ratio of pellets increases, the gas distribution in the furnace tends to shift from predominantly center flow to predominantly peripheral flow and thus to increase the pressure loss. In this case, the charging method should be improved to carry out closer gas distribution control.

\section{Summary}

The construction and operation of the Hirohata Pellet Plant have been described. The operation of the pellet plant is progressing smoothly with the product properties being at the level expected in the initial stage. Currently, efforts are being made to reduct the energy consumption level of the pellet plant and also to maximize the advantages of the unique characteristics of self-fluxing pellets as a blast furnace burden material.

\section{REFERENCES}

1) K. Fujita, T. Chiba and T. Sugiura: J. Min. Met. Inst. Japan, 18 (1973), 629.

2) T. Yatsuzuka, M. Yasunaga and Y. Shimomura: Tetsuto-Hagané, 60 (1974), S15.

3) Y. Shimomura and K. Fujita: Tetsu-to-Hagané, 60 (1974), S383.

4) Y. Shimomura, K. Okigawa and K. Hachisuka: Tetsu-toHagané, 60 (1974), S14.

5) K. Kojima and K. Nagano: Tetsu-to-Hagané, 57 (1971), S15.

6) S. Kondo, M. Sasaki and K. Ito: Tetsu-to-Hagané, 60 (1974), S12. 